\title{
PENGARUH AIR LIMBAH INDUSTRI TAHU TERHADAP LAJU PERTUMBUHAN TANAMAN BAYAM CABUT (Amaranthus Tricolor)
}

\author{
Eko Siswoyo $^{1)}$ dan Joni Hermana ${ }^{2)}$ \\ 1) Program Studi Teknik Lingkungan, Fakultas Teknik Sipil dan Perencanaan, Universitas Islam Indonesia, \\ Jl. Kaliurang Km 14,5 Yogyakarta \\ 2) Jurusan Teknik Lingkungan, Fakultas Teknik Sipil dan Perencanaan, Institut Teknologi Sepuluh November (ITS), \\ Jl. Arif Rahman Hakim, Sukolilo, Surabaya \\ eko_siswoyo@uii.ac.id
}

\begin{abstract}
The concentration of $B O D, C O D, N, P$ and $K$ in the tofu industrial waste is very high, therefore without appropriate treatment, it will become one of environmental problem. The recent study aimed to investigate the effect of tofu waste concentration on spinach plant growth. The plant is put in the plastic pot filled by mixed soil and humus and then added by tofu waste $(500 \mathrm{~mL}$ ) with different concentrations from $0 \%$ (balnk), 20\%, 40\%, 60\%, 80\% and 100\%. Parameters such number of leaf, surface of leaf, wet weight of leaf, dry weight of leaf and height of stem were measured after 15, 20, 25, 30,35 and 40 days. In order to measure the surface area of leaf, gravimetry method was used. The result of the study showed that after 40 days, pure tofu waste (100\%) have the best result for all parameters. This result indicated that high amount of organic substances in tofu industrial waste give ositive impact on the spinach growth, therefore it could be considered as fertilizer in the agricultural activities.
\end{abstract}

Key words: fertilizer, gravimetry method, organic substances, tofu waste, spinach.

\begin{abstract}
Abstrak
Air limbah industri tahu memiliki kadar BOD, COD, N, P dan K yang sangat tinggi, sehingga menjadi salah satu sumber pencemar bagi lingkungan jika tidak dikelola dengan baik. Penelitian ini bertujuan untuk mengkaji pengaruh konsentrasi air limbah industri tahu terhadap laju pertumbuhan tanaman bayam cabut. Tanaman uji diletakkan dalam sebuat pot yang berisi tanah campuran humus dengan perbandingan 1:5 dan kemudian diberi air limbah industri tahu (500 $\mathrm{mL})$ dengan konsentrasi yang berbeda mulai dari 0\% (kontrol), 20\%, 40\%, 60\%, 80\% dan 100\%. Parameter-parameter uji seperti jumlah daun, luas daun, berat basah daun, berat kering daun dan tinggi batang diukur pada hari ke-15, 20, 25, 30, 35 dan 40. Untuk mengukur luas daun digunakan metode gravimetri. Hasil penelitian ini menunjukkan bahwa pada hari ke-40, konsentrasi air limbah industri tahu 100\% memberikan hasil yang baik untuk semua parameter uji. Hal ini menunjukkan bahwa tingginya kadar bahan organik yang ada dalam air limbah industri tahu dapat diterima oleh tanaman uji, sehingga air limbah industri tahu ini dapat digunakan sebagai pengganti pupuk untuk kegiatan pertanian.
\end{abstract}

Kata Kunci : air limbah industri tahu,bayam cabut, bahan organik, metode gravimetri, pupuk..

\section{PENDAHULUAN}

Air limbah industri tahu memiliki berbagai kandungan bahan organik yang sangat tinggi, dimana hal ini jika tidak dikelola dengan baik akan dapat memberikan pengaruh negatif terhadap lingkungan. Secara umum air limbah industri tahu memiliki kadar BOD, COD, N, P dan K yang sangat tinggi. Kadar $\mathrm{N}$ total, $\mathrm{P}$ dan $\mathrm{K}$ dalam air limbah tahu mencapai 43,37 mg/L, 114,36 mg/L dan $223 \mathrm{mg} / \mathrm{L}$ (Kusumawati et al., 2015). Salah satu dampak akibat tingginya kadar N dan P bagi perairan adalah terjadinya eutrofikasi (Widyastuti et al., 2015). Hal ini jika tidak dikendalikan akan berakibat pada 
tumbuhnya alga yang tidak terkontrol (algae blooming).

Permasalahan yang sering muncul terkait pengelolaan limbah tahu adalah pengrajin industri tahu banyak yang berskala rumah tangga (home industry), dimana tidak tersedia anggaran yang cukup untuk mengolah air limbah tahu yang dihasilkan. Selain itu, masih terbatasnya ketersediaan sistem pengolahan air limbah industri tahu yang murah dan efisien juga menjadi kendala dalam mengolah air limbah industri tahu. Permasalahan lain dari belum terkelolanya limbah industri tahu dikarenakan minimnya pemahaman pelaku industri terkait penggunaan kembali (reuse) limbah industri tahu untuk kegiatan lainnya (Nasir, et al., 2015).

Salah satu upaya yang dapat dilakukan yaitu dengan memanfaatkan kembali air limbah industri tahu tersebut, misalnya untuk kegiatan pertanian. Keberadaan beberapa elemen dalam air limbah industri tahu seperti N, P dan K dalam jumlah tertentu diperlukan oleh tanaman untuk pertumbuhannya, namun jika jumlahnya berlebih akan dampak memberikan efek negatif. Konsentrasi air limbah tahu yang tepat dapat difungsikan sebagai pupuk cair untuk tanaman kangkung darat, dimana konsentrasi air limbah tahu $15 \%$ memberikan hasil yang paling optimal khususnya terhadap berat basah kangkung darat (Aliyenah et al., 2015). Pemberian limbah cair tahu dengan konsentrasi 15\% selama lima kali pada tanaman bayam cabut memberikan hasil yang paling optimal dibandingkan dengan konsentrasi limbah tahu 2\%, 5\% dan 10\% (Kusumawati et al., 2015). Pemberian air limbah tahu dapat dianggap sebagai pengganti pupuk cair organik, sehingga dapat memberikan hasil yang positif terhadap pertumbuhan tanaman uji. Perpaduan pupuk cair organik dan pupuk cair anorganik dapat memberikan hasil yang paling optimal terhadap pertumbuhan tanaman uji (Yap, 2012).

Penelitian-penelitian mengenai pengaruh air limbah tahu terhadap tanaman uji yang sudah dilakukan sebelumnya masih menggunakan konsentrasi air limbah tahu yang rendah sampai dengan 15\%, dimana dari penelitian-penelitian tersebut diketahui bahwa konsentrasi tertinggi memberikan hasil yang paling baik. Pada penelitian ini dilakukan pengujian pengaruh konsentrasi air limbah industri tahu terhadap laju pertumbuhan tanaman bayam cabut (Amaranthus tricolor), dimana konsentrasi air limbah tahu yang digunakan mulai dari $0 \%$ hingga $100 \%$. Hal ini penting untuk dilakukan guna mengetahui potensi penggunaan air limbah industri tahu murni sebagai penganti pupuk cair dalam kegiatan pertanian, sehingga nantinya diharapkan dapat mengurangi biaya produksi khususnya dari pembelian pupuk. Selain itu juga akan mampu mengatasi permasalahan pembuangan air limbah industri tahu ke badan air penerima yang berakibat pada terjadinya pencemaran lingkungan perairan. 


\section{METODE PENELITIAN}

\subsection{Material Penelitian}

Air limbah industri tahu yang digunakan dalam penelitian ini berasal salah satu pabrik tahu di Surabaya (PT. Tirta Buana), dimana pengambilan dilakukan satu kali selama pelaksanaan penelitian untuk menjamin homogenitas air limbah. Dalam penelitian ini digunakan tanaman bayam cabut (Amaranthus tricolor) sebagai tanaman uji dengan pertimbangan bahwa tanaman ini cepat tumbuhnya dan umurnya pendek (sekitar 40 hari). Benih tanaman bayam cabut yang digunakan berasal dari toko pertanian untuk mendapatkan kualitas tanaman bayam yang seragam dan berkualitas. Untuk media pertumbuhan tanaman uji digunakan tanah yang diambil dari ladang pertananian dengan ditambahkan humus dengan perbandingan 1: 5 (mendekati kondisi penanaman bayam cabut sesungguhnya) yang diletakkan dalam sebuah pot plastik berdiameter $18 \mathrm{~cm}$ dan tinggi $18 \mathrm{~cm}$ dan ditempatkan dalam sebuah rumah kaca untuk menghindari pengaruh dari air hujan dan hewan pengganggu.

\subsection{Pelaksanaan Penelitian}

Penelitian diawali dengan melakukan pembenihan tanaman uji di dalam reaktor, dimana setiap reaktor ditanam empat benih tanaman bayam cabut dan kemudian setelah tumbuh dipilih tanaman bayam yang mempunyai keseragaman (jumlah daun, ukuran daun dan tinggi yang sama) untuk digunakan sebagai tanaman uji. Pada saat pertumbuhan benih yang berlangsung selama dua minggu digunakan air ledeng (belum diberikan air limbah) untuk menjaga pertumbuhan tanaman. Setelah tanaman bayam cabut tumbuh dengan baik (umur tanaman 2 minggu), maka mulai diberikan air limbah industri tahu dengan variasi konsentrasi 0\% (kontrol), 20\%, 40\%, 60\%, 80\% dan 100\% (masing-masing konsentrasi berjumlah lima buah disesuaikan dengan waktu pengamatan). Waktu pengamatan pengaruh air limbah tahu dimulai pada hari ke-15, 20, 25, 30, 35 dan 40 disesuaikan dengan umur tanaman bayam cabut yaitu selama sekitar 40 hari.

Sistem pemberian air limbah yaitu dengan cara meletakkan reaktor ke dalam suatu wadah yang sudah diberi air limbah industri tahu dengan konsentrasi sesuai dengan variasi yang telah ditentukan. Limbah industri tahu akan diserap oleh tanaman, dimana volume air limbah yang diberikan yaitu sebesar $500 \mathrm{~mL}$. Hal ini didasarkan dari hasil uji pendahuluan dimana dengan kapasitas reaktor (ukuran pot plastik dan media tumbuh tanaman) tersebut kondisi tanah tidak terlalu basah.

Pengamatan yang dilakukan dalam penelitian ini yaitu pengaruh air limbah industri tahu terhadap pertumbuhan tanaman bayam cabut yang meliputi jumlah daun, luas daun, berat basah daun, berat 
kering daun dan tinggi batang. Pengamatan dilakukan setiap hari untuk mengetahui pertumbuhan dan kondisi tanaman uji secara visual dan setiap lima hari untuk mendapatkan data-data jumlah daun, luas daun, berat basan daun, berat kering daun dan tinggi batang tanaman bayam cabut. Pengukuran luas daun yang digunakan dalam penelitian ini yaitu metode gravimetri (Sitompul dan Guritno, 1995) dengan persamaan sebagai berikut:

$$
\begin{aligned}
& \mathrm{LD}=\mathrm{Wr} / \mathrm{Wt} \times \mathrm{LK} \\
& \text { dimana: } \\
& \mathrm{LD}=\text { luas daun }\left(\mathrm{cm}^{2}\right) \\
& \mathrm{Wr}=\text { berat kertas replika daun }(\mathrm{g}) \\
& \mathrm{Wt}=\text { berat kertas total } \\
& \mathrm{LK}=\text { luas kertas }\left(10 \times 10 \mathrm{~cm}^{2}\right)
\end{aligned}
$$

\section{HASIL DAN PEMBAHASAN}

\subsection{Karakteristik air limbah industri tahu}

Air limbah industri tahu yang digunakan dalam penelitian ini memiliki karakteristik sebagaimana yang terlihat pada Tabel 1. Terlihat bahwa kadar bahan organik dalam air limbah industri tahu yang digunakan sangat tinggi mencapai $3550 \mathrm{mg} / \mathrm{L}$ yang ditunjukkan dengan nilai $\mathrm{BOD}_{5}{ }^{20}$ serta memiliki nilai $\mathrm{pH}$ asam yaitu 4,9 .

Tabel 1. Karakteristik air limbah industri tahu

\begin{tabular}{lcc}
\hline \multicolumn{1}{c}{ Parameter } & Satuan & Nilai \\
\hline BOD $_{5}{ }^{20}$ & $\mathrm{mg} / \mathrm{L}$ & 3550 \\
$\mathrm{~N}$-total & $\mathrm{mg} / \mathrm{L}$ & 69,28 \\
P-total & $\mathrm{mg} / \mathrm{L}$ & 39,83 \\
$\mathrm{~K}$ & $\mathrm{mg} / \mathrm{L}$ & 616 \\
$\mathrm{pH}$ & & 4,9 \\
\hline
\end{tabular}

Sumber: hasil pengujian di laboratorium

Karakteristik dari air limbah industri tahu tersebut hampir sama dengan air limbah industri tahu yang dihasilkan dari beberapa tempat lain. Hal ini karena jenis kedelai dan jumlah air yang digunakan dalam proses pembuatan tahu relatif sama di beberapa tempat. Besarnya kadar N (69,28 mg/L), P (39,83 mg/L) dan K (616 mg/L) dalam air limbah industri tahu diharapkan menjadi pengganti substansi dalam pupuk yang biasa dipergunakan dalam kegiatan pertanian, sehingga memberikan dampak positif terhadap pertumbuhan tanaman uji.

3.2. Pengaruh konsentrasi air limbah industri tahu terhadap tanaman bayam cabut 
Keberadaan substansi organik yang terdapat dalam air limbah industri tahu dapat memberikan dampak negatif dan positif terhadap tanaman uji, dimana hal ini tergantung dari konsentrasi dari substansi tersebut. Hasil pengamatan mengenai pengaruh konsentrasi air limbah industri tahu terhadap jumlah daun tanaman bayam cabut ini dapat dilihat pada Gambar 1. Terlihat dengan jelas bahwa konsentrasi air limbah industri tahu $100 \%$ memberikan hasil yang paling baik. Hal ini menunjukkan bahwa besarnya konsentrasi BOD, N, P dan $\mathrm{K}$ dalam air limbah industri tahu diperlukan oleh tanaman bayam cabut untuk pertumbuhannya, termasuk pertumbuhan jumlah daun (Khalid, 2012). Selain itu juga perlu diperhatikan komposisi kadar C dan N di dalam media tanah agar memberikan hasil yang baik untuk pertumbuhan tanaman (Li et al., 2010).

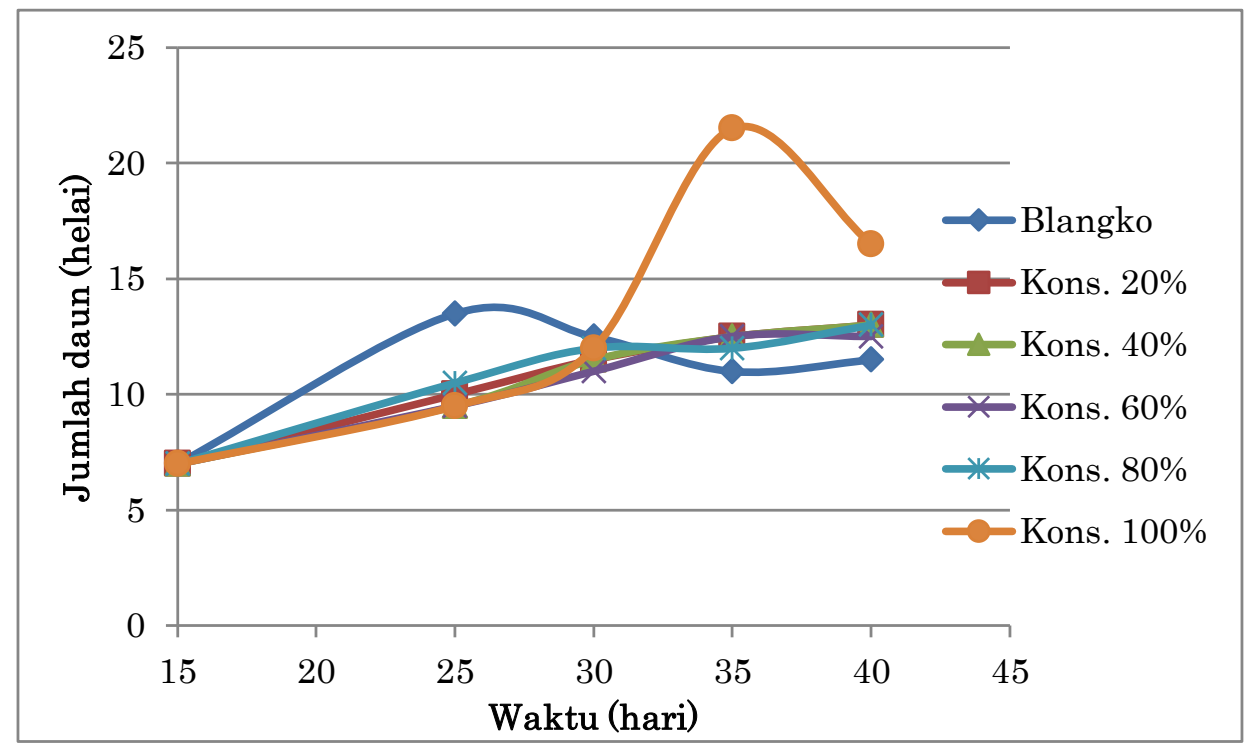

Gambar 1. Pengaruh konsentrasi air limbah industri tahu terhadap jumlah daun tanaman bayam cabut

Jika dibandingkan dengan blangko (tanaman uji tanpa diberi air limbah industri tahu), terlihat bahwa pada hari ke-40, jumlah daun tanaman bayam cabut nya paling sedikit. Hal ini dikarenakan air yang digunakan untuk penyiraman tanaman bayam cabut tidak terdapat nutrient-nutrien yang diperlukan untuk pertumbuhannya.

Pengaruh konsentrasi air limbah industri tahu terhadap luas daun, berat basah daun, berat kering daun dan tinggi batang tanaman bayam cabut selama periode waktu pengujian dapat dilihat pada Gambar 2 - Gambar 5. 


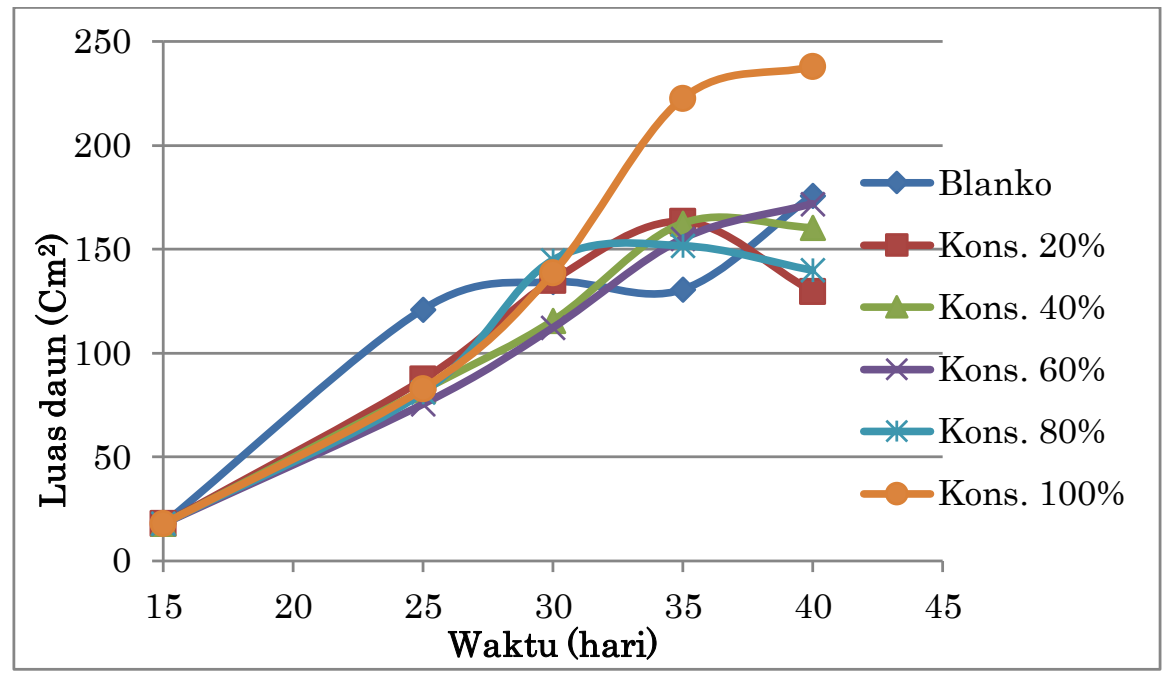

Gambar 2. Pengaruh konsentrasi air limbah industri tahu terhadap pertumbuhan luas daun tanaman bayam cabut

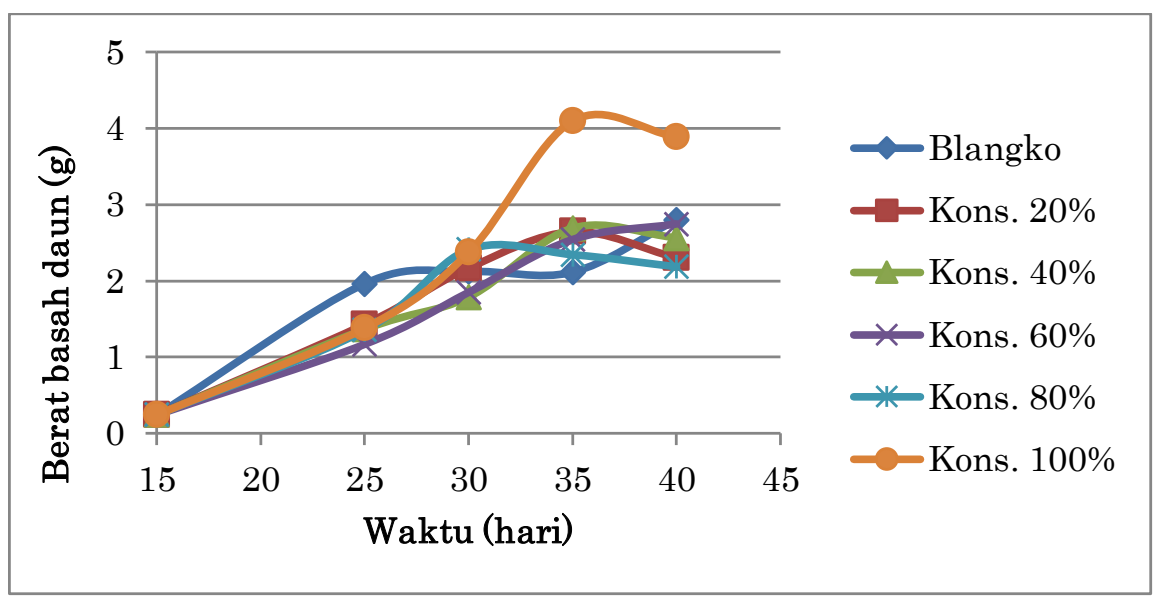

Gambar 3. Pengaruh konsentrasi air limbah industri tahu terhadap pertumbuhan berat basah daun tanaman bayam cabut

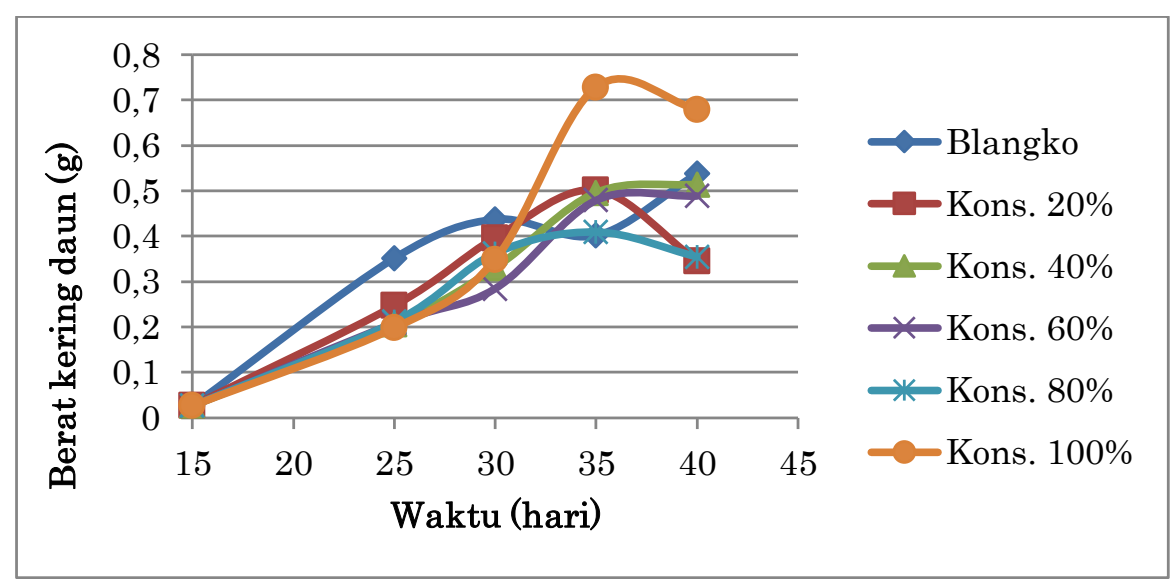

Gambar 4. Pengaruh konsentrasi air limbah industri tahu terhadap pertumbuhan berat kering daun tanaman bayam cabut 


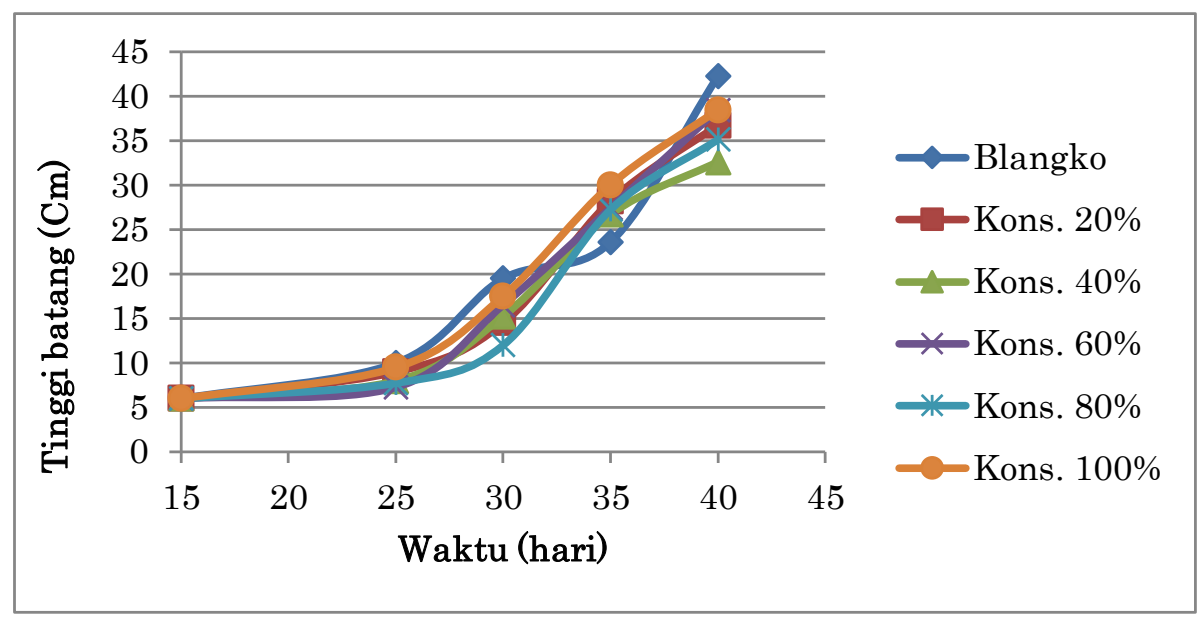

Gambar 5. Pengaruh konsentrasi air limbah industri tahu terhadap pertumbuhan tinggi batang tanaman bayam cabut

Data-data hasil pengujian menunjukkan bahwa konsentrasi air limbah tahu 100\% memberikan hasil paling baik dibandingkan dengan konsentrasi air limbah tahu lainnya. Keberadaan unsur-unsur N, P dan K dalam air limbah tahu yang dapat berfungsi sebagai pengganti pupuk, dimana hal ini mampu memberikan pengaruh positif terhadap pertumbuhan panjang dan luas permukaan akar serta cabang tanaman uji (Xie et 1., 2011).

\subsection{Toksisitas}

Keberadaan bahan-bahan organik dan anorganik dalam lingkungan akan memberikan pengaruh positif dan negatif terhadap tumbuhan, dimana hal ini sangat dipengaruhi oleh jenis dan konsentrasi dari bahan-bahan tersebut serta kemampuan tumbuhan dalam menerimanya. Dalam air limbah industri tahu, komponen yang paling dominan adalah karbon (BOD), N, P dan K, sedangkan kemungkinan keberadaan logam berat sangat kecil. Hal ini menjadikan tanaman uji dapat hidup dan berkembang secara normal dan bahkan lebih baik karena unsur-unsur tersebut diperlukan untuk pertumbuhan tanaman. Keberadaan logam berat dalam jumlah yang cukup besar akan bersifat toksik bagi tumbuhan, dapat mengakibatkan pertumbuhannya terganggu dan bahkan mati (Siswoyo et al., 2009). Setiap tumbuhan mempunyai batas toleransi tertentu dalam menerima unsur-unsur tertentu dari lingkungan. Penggunaan jenis pupuk dan model kegiatan pertanian (konvensional atau organik) akan memberikan efek terhadap tanaman uji dan juga potensi resiko terhadap kesehatan manusia yang mengkonsumsi tanaman tersebut (Rahmawati et al., 2017). Keberadaan loga berat seperti cadmium (Cd) dalam tanah akan menghambat pertumbuhan tanaman, dimana pemberian zat-zat organi khususnya asam humat dapat mengurangi pengaruh negatif dari logam berat tersebut terhadap tanaman (Chaab et al., 2016). 


\section{KESIMPULAN}

Penggunaan air limbah industri tahu dengan konsentrasi 100\% memberikan pengaruh paling baik terhadap pertumbuhan tanaman bayam cabut yang meliputi jumlah daun, luas daun, berat basah dan berat kering daun serta tinggi batang. Keberadaan unsur-unsur seperti N, P dan K dalam air limbah industri tahu diperlukan untuk pertumbuhan tanaman uji dan dapat berfungsi sebagai pengganti pemakaian pupuk dalam kegiatan pertanian. Hal ini akan mampu mengurangi biaya produksi khususnya dari penggunaan pupuk serta akan mampu mengatasi permasalahan pencemaran akibat buangan air limbah industri tahu.

\section{DAFTAR PUSTAKA}

Aliyenah, Napoleon, A., dan Yudono, B., (2015), Pemanfaatan Limbah Cair Industri Tahu sebagai Pupuk Cair Organik terhadap Pertumbuhan dan Produksi Tanaman Kangkung Darat (Ipomoea reptans Poir), Jurnal Penelitian Sains, Vol. 17 No. 3 pp. 102-110.

Chaab, A., Moezzi A., Sayyad, G., Chorom, M., (2016), Alleviation of cadmium toxicity to maize by the application of humic acid and compost, Life Science Journal, 13 (12), pp. 56-63.

Khalid, A., K., (2012), Effect of NP and foliar spray on growth and chemical compositions of some medicinal Apiaceae plants grow in arid regions in Egypt, Journal of Soil Science and Plant Nutrition, Vol. 12 (3) pp. 617-632.

Kusumawati, K., Muhartini, S., dan Rogomulyo, R., (2015), Pengaruh konsentrasi dan frekuensi pemberian limbah tahu terhadap pertumbuhan dan hasil bayam (Amaranthus tricolor L.) pada media pasir pantai, Vegetalika, Vol. 4 No. 2 pp. 48-62.

Li, R., He, X., D., Xue, P., P., Ci, H., C., Wu, W., Gao, Y., B., Zhao, H., L., (2010), Effect of soil nitrate: ammonium ratio on plant carbon: nitrogen ratio and growth rate of Artemisia sphaerocephala seedlings, Sciences in Cold and Arid Regions, Vol. 2 No. 5 pp. 0445-0454.

Nasir, M., Saputro, E.P., dan Handayani, S., (2015), Manajemen Pengelolaan Limbah Industri, BENEFIT Jurnal Manajemen dan Bisnis, Vol. 19 No. 2 pp. 143-149.

Rahmawati, S., Kirana, L., C., Yoneda, M., Oginawati, K., (2017), Risk Analysis on Organochlorine pesticides residu in potato and carrot from conventional and organics farms in Citarum watershed area, West Java province, Indonesia, Vol. 9 No. 1 pp. 1-15. 
Siswoyo, E., Kasam dan Widyanti, D., (2009), Penurunan Logam Berat Timbal (Pb) Pada Limbah Cair Laboratorium Kualitas Lingkungan UII dengan Menggunakan Tumbuhan Eceng Gondok (Eichornia crassipes), Jurnal Sains dan Teknologi Lingkungan, Vol. 1 No. 1 pp. 68-76.

Sitompul, S., M., dan Guritno, B., (1995), Analisis pertumbuhan tanaman, Gadjah Mada University Press, Yogyakarta.

Widyastuti, E., Sukanto dan Setyaningrum, N., (2015), Pengaruh Limbah Organik terhadap Status Tropik, RasioN/P serta Kelimpahan Fitoplankton di Waduk Panglima Besar Soedirman Kabupaten Banjarnegara, Biosfera 32 (1) pp. 35-41.

Xie, W., J., Wang, H., Y., Xia, J., B., Yao, Z., G., (2011), Influence of N, P, and K application on zea mays L. growth and $\mathrm{Cu}$ and $\mathrm{Pb}$ accumulation, Plant Soil Environmen, 57 (3) pp. 128-134.

Yap Chin Ann, (2012), Impact of Different Fertilization Methods on the Soil, Yield and Growth Performance of Black Pepper (Piper Nigrum L.), Malaysian Journal of Soil Science, Vol. 16, pp. 71-87. 